\title{
THE PROVISIONS RELATING TO TRIAL PRACTICE IN THE NEW ILLINOIS CIVIL PRACTICE ACT
}

\author{
EDSON R. SUNDERLAND*
}
7 HERE are six major subjects in the field of trial practice which have been substantially affected and improved by the new Civil Practice Act.

The amalgamation of the rules for legal and equitable proceedings may be designated as the first of these. Inasmuch, however, as this is a subject which affects pleading more profoundly than trial practice, it can be more appropriately dealt with in the division relating to pleading, and is therefore omitted here.

The remaining subjects will be taken up as follows: (I) The Rule-Making Power, (2) Venue and Service of Process, (3) Summary Judgments, (4) Discovery before Trial, and (5) The Use of Juries.

\section{THE RULE-MAKING POWER}

The new Illinois Civil Practice Act departs from the immemorial tradition of the state by conferring a very extensive rule-making power upon the Supreme Court. By this grant the Supreme Court is given authority to regulate the rules of pleading, practice and procedure in all courts of record in the state, except the Municipal Court of Chicago, but it is provided that such regulation shall be supplementary to, not inconsistent with, the legislative provisions of the Act, which are set forth in $94 \mathrm{sec}-$ tions. A schedule of $4 \mathrm{r}$ rules is attached, but although they received legislative approval as a part of the Act, they were expressly declared to operate only as rules of court, subject to such suspensions or amendment by the Supreme Court as experience might show to be expedient.. When, therefore, the Act goes into effect on January I, I934, the procedure of Illinois will be partly a legislative system and partly a court rule system.

The method thus adopted is a familiar one for inaugurating and restricting judicial control of legal procedure. The English Judicature Act of I873 consisted of a statute of Ioo sections with an attached schedule of 58 rules. ${ }^{2}$ The Connecticut Practice Act of 1879 was a statute of 34 sections which contained a provision that the judges of the superior court should, prior to its becoming operative, prepare and file a schedule of orders and

* Professor of Law and Legal Research, the University of Michigan Law School.

$x \S \S 2$ and 3 .

${ }^{2} 36 \& 37$ Vict. c. 66. 
rules necessary and proper to give it full effect. There were two or three hundred of these rules published in the Connecticut Practice Book. The New Jersey Practice Act of I9I 2 consisted of a statute of 33 sections with an attached schedule of 83 rules. ${ }^{3}$ The New York Civil Practice Act of I920 consisted of a statute of 1578 sections, to which was added, under legislative authorization, a schedule of 300 rules not inconsistent therewith, drawn and promulgated by a convention whose membership was prescribed by the legislature. ${ }^{4}$ The statute and rules were.officially published together in I92I under the title, The Civil Practice Act, and went into effect on October $\mathrm{r}$, of that year.

The chief difficulty in such an arrangement comes in drawing the line between those matters which are to remain under legislative control and those matters which are to be turned over to the court to be regulated by rules.

The English plan has been to limit as far as possible the active participation of the legislature in the regulation of procedure, and to place the matter almost wholly under judicial control. In the Common Law Procedure Act of 1852,5 parliament enacted a complete code of procedure, but at the same time provided that the judges should retain full power to make any rules affecting pleading and practice that they might deem expedient, anything in the Act to the contrary notwithstanding.

The English Judicature Act of 1873 , following the same general theory, confined the legislative provisions almost entirely to matters of court organization and jurisdiction. They consolidated the existing courts into a single court, established operating divisions, prescribed the judicial personnel together with their tenures, duties, salaries and retiring pensions, fixed the jurisdiction and described how it should be administered, provided for sittings and the distribution of business, defined the powers of subordinate court officers and left practically everything else to be regulated by rules.

The American plan has been a very different one. Instead of drawing the line between the organization and powers of the court on the one hand, and its methods of operation on the other, and reserving legislative control over the former while delegating the latter to the judges, we have proceeded upon the theory that not only should the legislature deal exclusively with questions of jurisdiction and judicial organization, but also with the more fundamental principles of procedure. Rights are so largely dependent upon remedies, that our people have usually been unwilling to

3 Laws of rgr2, c. 23 r.

4 Laws of 1920 , c. 902 .

$s_{15} \& 16$ Vict. c. 76. 
surrender to the judges the power of determining the nature or scope of remedial processes, and have limited their authority to the regulation of operating details.

It was upon this theory that the Connecticut Practice Act was drawn in r879, five years after the Judicature Act was adopted in England. The English act was entirely familiar to those who drafted the Connecticut legislation, and in many ways it served as a model. But the scope of the legislative provisions was much more comprehensive, and that of the rules much more restricted, than in the English act. The substance and form of pleadings and demurrers, joinder and change of parties, amendment of pleadings, employment of cross claims, use of attachment, manner of utilizing juries, and the granting of new trials, were all dealt with in the legislative portion of the act. The rules, when added pursuant to the statute, regulated the admission of attorneys to practice, the time for doing various acts, the method of handling calendars, the mechanics of proceedings in court, costs and fees, the operations of receivers, the taking of depositions, findings by the court, hearings on damages, manner of preparing records and raising issues on appeal, and a large number of detailed rules of pleading supplementing those set forth in the statute, including a liberal supply of model pleading forms. ${ }^{6}$

New Jersey, in $\mathrm{x} 9 \mathrm{x} 2$, followed the same system. The legislative portion of the Practice Act dealt with the more furdamental principles relating to pleading, parties, summary judgments, amendments, new trials, and appeals, while the schedule of rules supplemented the details of practice in regard to the same subjects and provided suitable forms of precedents.

The New York Civil Practice Act is much more elaborate than either the Connecticut or New Jersey act, and both the statutory provisions and the rules of court which accompany them are more numerous and more detailed. The distribution of material between statute and rules was obviously made with at least some reference to the general theory that the more fundamental and controlling principles ought to be accorded greater permanency and stability by being placed in the statute, while the mechanics of procedure should enjoy the advantage of more flexibility by being subject to adjustment under rules of court. But in the actual result a great deal of procedural detail found its way into the act. This was to be expected, for a legislature accustomed to exercise entire control over every phase of judicial procedure would be likely to view with alarm any bill which proposed too extensive a curtailment of its power.

However, when once the step has been taken of dividing the field of

${ }^{6}$ See the Connecticut Practice Book. 
procedure between the legislature and the courts, the inevitable tendency will be to withdraw more and more matters of detail from the statute and include them in the rules. This process will proceed as rapidly as the public can be convinced that the courts can successfully deal with the problem of regulation. Already the profession in New York is preparing to urge a redistribution of procedural material. A Committee on Court Rules appointed by the Association of the Bar of the City of New York has just issued an exhaustive report of 825 pages in which every section of the practice act has been analyzed with a view to determining whether it should be left in the act or should be transferred, in whole or in part, to the rules. The committee concludes that more than half of the sections in the act ought to be distributed among the rules of court, and an effort will be made at the next session of the legislature to secure the passage of an amended practice act consisting of 753 sections of the statute and 1346 rules of court, instead of 1578 statutory sections and 3 or rules.

Illinois has followed the same course as Connecticut, New Jersey and New York. It has conferred substantial rule-making power upon the Supreme Court while at the same time the major part of the field of procedure still remains under the control of the legislature. Every reform is a compromise. The tradition for statutory regulation, which had continued unbroken during the entire history of the state, was probably too firmly established to justify any attempt to entirely supplant it.

Through the exercise of the limited power granted the court will be able to build up a technique for dealing with procedure through rules of court, and as the public becomes convinced of the court's ability to make rules which will produce a business-like administration of justice, the legislature will be less reluctant to delegate fuller power.

\section{VENUE AND THE SERVICE OF PROCESS}

a) VENUE

No subject in the field of judicial procedure has produced more widely divergent rules than that of the venue of actions.

At the early common law every action was local. This was due to the necessity of finding a jury of triers who were familiar with the facts of the case and could render a verdict on their own knowledge, since no evidence was introduced before them. The jury were subject to attaint for a false verdict because they were the witnesses whose testimony, given in the jury room, was transformed directly into the verdict rendered. Qualified jurors could ordinarily be found only where the transaction occurred. ${ }^{7}$

7 Crook v. Pitcher, 6I Md. 5 IO (I883). 
England passed from this theory of venue in which every action was local, to a theory in which no action was local. Order 36 , Rule Io of the English Rules now provides that "there shall be no local venue for the trial of any cause, matter or issue, except where otherwise provided by statute." But since the rule was originally enacted without the exception, as a part of the Judicature Act of 1875 , it operated in that form to repeal the venue provisions in every Act of Parliament passed prior to that date, and the subsequent introduction of the exception in 1883 did not revive them. ${ }^{8}$ The result is that practically any action can be commenced anywhere, and its place of trial will be fixed by order in accordance with the balance of convenience.?

In the United States we have proceeded upon the assumption that the place of bringing suit and the place of trial shall be the same, subject to special provisions for change of venue, and we have tried almost every conceivable principle of limitation in fixing that place by general rules.

Obviously there is no essential jurisdictional matter involved in the question of venue, and the only consideration that ought ever to control is convenience.

Assuming that the courts of all the counties of the state are equally well equipped to dispose of cases within their competency, and this would usually be true, the points of incidence of the principle of convenience would be: (I) The convenience of the plaintiff; (2) The convenience of the defendant; and (3) The convenience of the witnesses. Each of these has exerted an influence in the framing of rules of venue, and since they are often mutually antagonistic, the results have been confusing.

In general our laws have somewhat favored defendants as against plaintiffs, on the theory, probably, that since the plaintiff controls the institution of suit he might behave oppressively toward the defendant unless restricted. Accordingly, many statutes require transitory actions to be brought in the county of a defendant's residence, which, of course, generally serves his convenience. In other states this protection accorded to the defendant is subject to a limited right in the plaintiff to elect to enjoy the advantage of convenience so far as it may be done by suing in the county of his own residence, but no further. Since the principle of convenience is a sound one to employ, and it is impossible in any event to frame general rules which will always operate equitably as between the parties, either of these provisions has something to commend it.

Illinois has heretofore failed to provide restrictions which would make venue even theoretically dependent upon anyone's convenience. This has

${ }^{8}$ Buckley v. Hull Docks Co., [I $\left.\varepsilon_{93}\right]$ 2 Q. B. 93.

. ${ }^{9}$ Order 36 , rule Io, par. 2. 
resulted from authorizing suit to be brought in any county where the defendant resided or might be found. Obviously the place where a defendant happens to be at the moment when a process-server hands him a copy of a summons, may have no relation whatever to the convenient trial of the action, and it may actually be, either through accident or design, the place of maximum inconvenience. The new Civil Practice Act has withdrawn the privilege of bringing suit in any county where the defendant happens to be found, although it still permits it to be brought where the defendant resides. ${ }^{10}$ But the place of plaintiff's residence is not a basis for venue.

To prevent juggling with venue by joining an additional defendant residing in some other county for the sole purpose of bringing the action there, good faith and probable cause in joining such defendant are made conditions upon which judgment may be rendered solely against defendants residing in such county. ${ }^{\text {II }}$

Convenience of witnesses constituted no basis for fixing venue under the former practice in Illinois, except in so far as this might result from the doctrine requiring local actions to be brought where the subject matter was situated.

To facilitate such convenience any transitory action may hereafter be brought in the county "in which the transaction or some part thereof occurred out of which the cause of action arose." This is a recurrence to the principle by which venue was fixed at common law when all actions were deemed to be local, but its use is optional, not compulsory. It will enable the convenience of witnesses to be served in cases where the evidence is largely available in the place where the facts occurred which constituted the cause of action or some part of it.

Finally, local actions are definitely defined in order to remove any uncertainty regarding their identity. ${ }^{\mathbf{1 3}}$

\section{b) SERVICE OF PROCESS}

Process serving is one of the major revenue-producing activities connected with the courts. Where service by an officer is required, the aggregate amount of fees and allowances for mileage is very large, and in some of our cities the number of deputies who share in the proceeds of this tax on litigation is almost incredible.

To withdraw this lucrative source of income from the army of official beneficiaries, by a general authorization of service of summons by private persons, would be a political task of the first magnitude. It was not attempted in the Illinois Civil Practice Act, but a slight step was taken in
ro $\S 7$.
II $\S 7$.
$12 \$ 7$.
$x_{3} \S 9$. 
that direction by the provision that service shall be made by the sheriff or coroner "unless the court shall order service to be made by some other person." ${ }^{2}$ No restrictions or conditions are laid upon the court in connection with the exercise of this power. What use will be made of it remains to be seen.

As an aid to the prompt service of process, county boundaries no longer constitute any obstacle to the official process-server. But expensive journeys by officers to distant parts of the state are discouraged by means of a provision that mileage cannot be taxed as costs where an officer travels outside his county. ${ }^{15}$

Important changes in the provisions relating to the manner of service of process were also introduced. In making them the following principles were employed: Since service of process is absolutely vital to the exercise of jurisdiction by courts, and since this duty is to be performed by administrative officers with little or no training in the law, the procedure should be as simple and comprehensive as possible, described in language easy to understand and follow, subject to no limitations or distinctions which are not obviously essential, and should be conveniently applicable to the contemporary conditions confronting process-servers.

To meet these requirements the confused, incomplete, and elaborately differentiated provisions scattered through different chapters of the statutes were replaced by a few simple sections which provided for:

(a) Employment of the same methods of service, personal or by publication, in all proceedings, whether legal or equitable.

(b) An alternative method of personal service upon an individual, by leaving a copy at his usual place of abode with a person of the family of ten years or upward, explaining its nature to that person, and sending an additional copy to the defendant by mail to the same address. ${ }^{16}$

(c) A single method of personal service upon all private corporations by serving any officer or agent found in the county of venue, or, if no such person is found there, then by serving such officer or agent in any other county. ${ }^{17}$ The absurd requirement that an attempt be first made to serve the president is eliminated.

(d) A single method of personal service upon all municipal or other public corporations by serving designated officers. ${ }^{8}$

(e) A single method of personal service upon all receivers or trustees of incorporated companies by serving the receiver, trustee or any agent in the county of venue if possible, otherwise by serving him in any other county. ${ }^{\text {I9 }}$
I4 $\S 6$.
${ }^{25} \S$ ro.
re $\S I_{3}$.
$17 \S 17$.
s8 $\$ 18$.
$19 \S \mathrm{xg}$. 
(f) The use of service by publication and mail against private corporations, or their receivers or trustees where no officer or agent can be found in the county of venue. ${ }^{20}$

\section{SUMMARY JUDGMENTS}

The common law system of procedure furnished a highly developed technique for raising and trying issues of fact, but it provided no method for a preliminary determination as to whether the issues were real or fictitious. Issues raised in pleadings were always appraised at their face value, and were all deemed equally worthy of a formal trial. As a result either party was always able, if he so desired, irrespective of the merits of his position, to compel his opponent to endure the delay and incur the expense of a trial before a jury.

When a pleading presents a disputed matter of fact, one party having asserted and the other having denied its truth, two questions are involved -First, Is the dispute a real one? Second, If it really exists, how should it be decided on its merits? Obviously, if it is not a real dispute, and the evidence is all on one side, the case ought not to proceed to trial at all, for there is nothing to try. If this could be conveniently ascertained at an early stage, before time has been wasted in waiting for the case to be called, and before money and effort have been expended in the preparation and presentation of evidence, the efficiency of the courts as instruments of justice would be vastly increased. Particularly would this be true in regard to the collection of debts, where defendants have been able, for long periods, by denials which are wholly false and fictitious, to paralyze the arm of the law.

Whether or not an allegation or a denial is made without any basis of fact can never be ascertained from the pleading in which it is found, for pleadings do not disclose the evidence upon which they rest. To determine that question it would be necessary to compel the pleader to disclose the evidence upon which he relies in making the allegation or denial. If, in such case, he is able to make a sufficient showing to indicate the existence of a bona fide dispute, the case should be set for trial; if he is not able to do so, the case should be ended then and there by the entry of a judgment in accordance with the undisputed facts.

Now, it is a much simpler problem to determine whether a substantial dispute exists than to decide the dispute itself upon its merits. If the issue raised upon the pleading has no basis in fact, and there is no evidence upon which the allegation or denial can be legitimately predicated, its fictitious

20 $\$ \$ 17,19$. 
character will immediately appear as soon as the pleader lays his cards upon the table. All that is necessary is a simple procedure for requiring a party, upon the demand of his opponent, to show what evidence he has in support of his position.

The intense commercial activity which followed the industrial revolution in England in the middle of the nineteenth century brought an insistent demand for a speedier method of dealing with actions based upon commercial paper. Business men were unwilling to submit to the delay and expense caused by the inability of the common law courts to quickly identify and summarily dispose of fictitious defenses.

Accordingly, in 1855 , Parliament passed the first English summary judgment act, which was entitled "An Act to facilitate the Remedies of Bills of Exchange and Promissory Notes by the Prevention of frivolous or fictious Defenses to Actions thereon." ${ }^{2 x}$ The act provided that a notice should be indorsed upon the writ by which suit was commenced, to the effect that unless the defendant within $\mathrm{I} 2$ days obtained leave of court to appear, the plaintiff would be at liberty to sign final judgment for the amount claimed to be due on the bill or note, and that leave to appear could be obtained only on affidavit showing that there was a defense on the merits or that it was reasonable that the defendant be allowed to appear.

This was an absolute reversal of the common law theory that a defendant had a right to set up and go to trial upon any issue he pleased, and that the genuineness of his defense could not be questioned in advance of the trial itself. Under this statute the plaintiff was presumed to have a valid claim when suing on a bill or note, and the defendant was presumed to have no bona fide defense whatever. This presumption against the defendant could be removed only by producing sufficient evidence by way of affidavit to show the probable existence of a good defense.

The essential feature of this procedure was the withdrawal of the right to raise issues and bring them to trial without first making preliminary persuasive proof of the existence of the facts upon which they were based.

Both the mechanism of English summary judgment procedure, and the scope of its operation, have undergone extensive development since the device was first employed in 1855 .

The remedy has been broadened to apply to any action for the recovery of a debt or liquidated demand payable in money arising upon a contract, express or implied, or on a bond or contract under seal, or on a statute (other than for a penalty) or on a trust, and to any action by a landlord

${ }^{21}$ I8 \& 19 Vict. c. 67 . 
against a tenant for the recovery of the possession of land, and to any action for the recovery of possession of specific chattels. ${ }^{22}$

The legal presumptions which originally sustained the prima facie validity of the plaintiff's demand and the prima facie lack of any defense, have been removed, and the plaintiff is now required to establish a prima facie case by swearing to the truth of his claim, and to raise a presumption against the existence of any defense by stating his belief that there is none. Upon this basis there at once arises a prima facie right in the plaintiff to a final judgment in his own favor, and the defendant can prevent the immediate entry of such a judgment only by a disclosure of evidence sufficient to show that there are facts which either constitute a good defense on the merits or which ought to entitle him to defend at the trial.

The experience of England with this summary procedure demonstrates the amazing fact that the vast majority of cases brought into court involve no real issues at all. What the plaintiff ordinarily wants is only the aid of the court in enforcing an undisputed claim. In the year $x$ 93I there were 5,434 summary judgments rendered in the King's Bench Division as against only $\mathrm{I}, 240$ judgments rendered after the trial of issues. ${ }^{23}$

Illinois has long had an authorized statutory practice which superficially resembles the summary procedure here described. ${ }^{24}$ But it lacked the indispensable element necessary for identifying fictitious defenses, namely, a preliminary showing of the evidence upon which the defendant claimed to rely. Instead of being required to make such a disclosure of evidence, the defendant or his agent or attorney was permitted to file a sworn statement in the form of a conclusion that "he verily believes the defendant has a good defense to said suit upon the merits," with a specification of its nature. This is practically useless as a means for ascertaining whether or not the defendant has a bona fide defense. A party who feels justified in carrying his refusal to pay a debt so far as to force his creditor to bring suit against him, will usually find it easy to persuade himself that there are good grounds for the refusal, particularly when assisted by the ingenuity of counsel. Such an affidavit was hardly more effective as a protection against fictitious defenses than the signature of counsel which the common law required to be attached to the plea.

The new Civil Practice Act has given Illinois a summary judgment procedure much superior to that in England. ${ }^{25}$ The cases coming within its scope are essentially the same. Some of its operative features are some-

${ }^{22}$ Order ${ }_{44}$, rule $\mathrm{I}$; Order 3 , rule 6.

${ }^{23}$ Civil Judicial Statistics, England and Wales, r931, Table IX, p. I6.

24 Ill. Cahill's Rev. Stats. (193r), c. r ro, $\$ \S 55,56$.

$25 \S 57$. 
what different because the Illinois court organization has no officers corresponding to the English masters who largely administer the summary judgment procedure by personal conference with solicitors representing the parties. Other features of the Illinois procedure are distinct improvements upon the English model.

The English summary judgment practice has an element of unfairness. While the defendant may be required to make a full disclosure of his evidence in order to avoid a summary judgment, the plaintiff is required to make no such disclosure in order to obtain one. If made equally by both parties, disclosure of evidence would put neither one at a relative disadvantage, while a one-sided disclosure might often prove seriously damaging.

An English plaintiff risks nothing in demanding a summary judgment. His showing of merits consists only of swearing to the truth of the material facts constituting his claim, without disclosing the evidence by which he expects to establish them. If the application for a summary judgment fails, he is in no worse position to go on with the case than if he had not made it. But the defendant is not so fortunate. If the case proceeds to trial he is in the position of one who plays against a hand which he has never seen after having exposed his own hand to the inspection of his opponent.

This differential in favor of the plaintiff has been removed in the Illinois Civil Practice Act. The plaintiff can no more obtain a summary judgment without disclosing evidence of the merits of his claim, than the defendant can prevent its entry without a similar disclosure regarding his defense. Each one must set forth by affidavit the facts upon which he replies, stating them not by way of conclusions but in a form suitable to offer in evidence, with the further showing that the affiant, if sworn as a witness, could testify competently thereto. If all the facts are not within the personal knowledge of one person, two or more affidavits must be used. And copies of all documents relied upon must be attached to the affidavit. ${ }^{26}$

Should necessary facts be personally known only to persons who are unavailable or hostile to the party filing the affidavits, this situation may be shown therein and the court may then deal with the matter as may be fair and just, by allowing a continuance for obtaining affidavits, or by ordering the submission of interrogatories or by the taking of depositions. ${ }^{27}$

The requirement of a fully mutual disclosure of the same kind from both ${ }^{26} \S$ I02 (rule 8) (1), (2). 27 \& IO2 (rule 8) (3). 
parties, follows the practice in New York ${ }^{28}$ and Michigan, ${ }^{29}$ as it has been developed in those states through a broad experience of a number of years.

But the new Illinois act, while requiring mutuality of disclosure, falls short of the New York rule in regard to mutuality of remedy. In Illinois it is only the plaintiff who is authorized to ask for and obtain a summary judgment, while in New York either party may do so. This is a recent development in that state, where the remedy has undergone a remarkable expansion under the active direction of Presiding Justice Edward $R$. Finch, of the Appellate Division, First Department. ${ }^{30}$

New York has also radically extended the scope of the remedy by making it available in actions for unliquidated damages for breach of contracts, for foreclosure of liens or mortgages, for specific performance of contracts, and for accounting. In all of these actions it may be necessary to take testimony to determine the amount of the judgment or the proper terms of the decree, and it is of course entirely possible to do so. The experience of New York in expanding the use of this highly effective modern remedy should receive the close attention of the profession in other states. Chicago lawyers will doubtless be particularly interested in the results obtained in New York City.

\section{DISCOVERY BEFORE TRIAL}

The Civil Practice Act has delegated to the Supreme Court, in the broadest terms, full authority to regulate the entire field of discovery be-

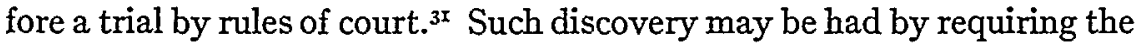
listing and submission of documents, by requesting admissions of facts, or by the taking of depositions. The schedule of rules attached to the act provides a complete procedural mechanism, of the most liberal type and of the widest scope, for obtaining discovery by each of these methods. ${ }^{32}$

No system of pleading used in any English-speaking country has ever furnished an adequate basis for preparation for trial.

In order to properly prepare to meet the case which will be presented against him, a party must have information of two kinds. First, he must know what material facts his opponent will undertake to establish or deny, and second, he must know what evidence will be employed for that purpose. The pleadings give very inaccurate information as to the first of

${ }^{28}$ Rule 113 of the Rules of Civil Practice.

${ }^{29}$ Rule 30 , Revision of $193 \mathrm{x}$.

${ }^{3 \circ}$ Amendment of June 15 , 1933. See Summary Judgment Procedure, by Hon. Edward R. Finch, I9 Am. Bar Ass'n. Jour. 504-508 (Sept. 1933).

${ }^{3 x} \S 58$.

${ }^{32}$ Secs. ro3 (rule 9), ro4 (rule ro) and ro5 (rule Ir). 
these matters, and they give no express information at all as to the second.

A pleader is never required to prove or even to attempt to prove all the allegations in his pleading. He cannot, of course, introduce evidence upon any matter not alleged, but he may assert in his pleading whatever facts he chooses without any regard to the actual possibility of proof. All or any of his allegations may be entirely without evidentiary foundation, and the other party may find at the trial that he has laboriously marshalled his forces to meet an attack either purely imaginary or much less extensive than he was led to believe.

Denials may be made with similar disregard of the truth. There is no way of ascertaining from the pleadings whether or to what extent issues are raised for the purpose of really contesting the truth of allegations, or for the purpose of concealing the real point of attack, or with the deliberate design of embarrassing the other party by forcing him to produce evidence in support of matters not actually in dispute.

Fictitious issues of any of these types cannot be identified by anything less than a disclosure of the evidence which the pleader has at his command, but this is a matter with which the pleadings themselves do not deal.

Even in regard to the issues which are presented fairly and in good faith, the requirement that the pleadings shall contain only generalized statements and denials of so-called ultimate or material facts, without any indication of the nature of the proof by which they are to be supported, enormously diminishes their value as a basis for preparation for trial. It is the evidence that will be introduced against him which a party must be prepared to meet, and the pleadings give very little indication as to what that will be. Allegations of promises, for example, may be proved in many ways,-by letters, conversations, telephone messages, telegrams, personal conduct, or acts, of persons claimed to have been agents either by authorization or ratification. It is frequently impossible to adequately prepare to defend such cases unless one has some information as to the nature of the proof to be offered in their support.

Neither the English common law nor English equity made any substantial contribution to this problem of supplementing the pleadings with further information sufficient to make the trial a well-organized presentation of the merits of the case instead of a contest in which each party attempts to overwhelm his opponent by unexpected attacks from ambush. Bills of particulars and the profert of deeds sometimes offered a modicum of relief, but they served chiefly to demonstrate the need for a radical im- 
provement in the system. Equity did nothing at all, for its bills for discovery, as well as interrogatories which it authorized in bills for relief, related only to the evidence which the pleader himself sought in order to establish his own case, not to the evidence of his adversary which he would be required to meet at the trial. Discovery in equity was only available for attack, never for defense.

In order to give the parties a better opportunity to prepare for trial, and thereby make litigation more of a business risk and less of a lottery, statutes have been enacted in most states improving the methods and enlarging the scope of discovery before trial. Illinois has heretofore occupied a position about midway between the most progressive and the least progressive states. It has allowed the taking of depositions of witnesses in chancery with considerable liberality, ${ }^{33}$ but aside from the depositions of witnesses resident in other counties, or about to leave the state or unable to attend court, almost nothing has been done to facilitate discovery in actions at law, ${ }^{34}$ although a rather broad use of interrogatories has been permitted in the Municipal Court of Chicago. ${ }^{35}$

The new Civil Practice Act gives Illinois a discovery practice second to none in the United States.

Discovery of documents is the first major division of the new procedure. This may be had on motion without any affidavit, which makes an order of allowance available practically as a matter of course unless special cause be shown to the contrary. ${ }^{36}$ When the order is made, the documents relating to the matter in issue are to be listed by descriptive titles in two schedules: ( $I$ ) consisting of those which the party is willing to produce, and (2) consisting of those which he is not willing to produce, with a statement of the reasons on which his objection is founded. All documents listed in schedule I may be inspected and copied at any convenient time, with penalties for unreasonable refusal. ${ }^{37}$ Documents in schedule 2 may be inspected or copied only on special order made on motion of the party seeking inspection, with penalties for failure to obey the order. ${ }^{38}$ No document not listed shall be admissible at the instance of the party failing to list it, ${ }^{39}$ and neither those documents listed in schedule $I$ which are not produced, nor any documents listed in schedule 2 , shall be prima facie admissible at the instance of the party listing them. ${ }^{40}$ Supplementary lists may be subse-

33 Ill. Cahill's Rev. Stats. (I93I), c. 5I, \$ 24.

34 III. Cahill's Rev. Stats. (I93 X), c. 5I, \$\$ 25-26.

35 Ill. Cahill's Rev. Stats. (I931), c. $37, \S 420$.

${ }^{36} \&$ ro3 (rule 9) (I).

$37 \S 103$ (rule 9) (2).

${ }^{8} 8$ I03 (rule 9) (3).

39 \& ro3 (rule 9) (4).

$4^{\circ} \S$ I03 (rule 9) (5), (6). 
quently filed. Any party may move at any time for an order to produce any specified documents, ${ }^{4 \mathbf{x}}$ or for an order that any other party file affidavits showing what has become of any documents formerly in his possession. ${ }^{42}$

Subsection (I) of the foregoing rule, so far as it provides for an order and a listing of documents, substantially follows English Order $3 x$, Rules I2, I3. Subsections (3) to (7), dealing with the inspection of the two classes of documents, providing penalties for obstructing the discovery, prohibiting a party who fails to list or produce a document from using it as proof in his own behalf, and permitting supplemental lists, have been added as convenient auxiliary provisions to make the proceeding more effective, but they do not appear in the English Order. Subsections (8) and (9) substantially follow Rule I40 and Section 328, respectively, of the New York Civil Practice Act of r $92 x$. Subsection (ro), providing for stay of proceedings, pending compliance with an order, is taken from Michigan Rules (Revision of I93I) Rule 40, Section 6. The entire Rule provides a fully articulated procedure for discovery of documents.

Discovery by request for the admission of specific facts, or of the genuineness of specific documents, is the second main feature of the new procedure.

This practice substantially follows English Order 32, Rules 2 and 3 . It has been used in New York since $192 \mathrm{x},{ }^{43}$ and in Michigan since I93r. ${ }^{44}$ Its purpose is not only to discover facts but to save expense by substituting an admission for formal proof.

Discovery by deposition is the third and most important branch of the discovery procedure provided by the new Civil Practice Act.

In regard to the method by which discovery by deposition is to be obtained, the Illinois Act is much superior to the present English rules.

In England, discovery cannot be had by means of depositions taken on oral examination, but the only method available is by submitting written interrogatories to the parties whose testimony is wanted. ${ }^{45}$

The use of written interrogatories is a very ineffective way of obtaining information from hostile parties, for several reasons. In the first place, it gives the interrogated witness full advance notice of the questions to be answered, and an opportunity to study the effect of various possible answers and to frame responses in such a way as to reveal as little as possible which will be injurious to the deponent. For this reason the interroga-

${ }_{45}$ § I03 (rule 9) (8). 42 \& ro3 (rule 9) (9).

${ }_{43}$ New York Civil Practice Act, $\$ \S 322$ and 323 .

44 Michigan Court Rules ( $993 \mathrm{I})$ rule $42, \S \S \mathrm{I}$ and 2.

45 Order 3 , rule $x$. 
tories tend to become excessively numerous and detailed, in order to forestall the deponent's attempts to conceal or evade. In the second place, the method is far less searching than an oral examination, for all the questions must be drawn in advance and the line of questioning cannot be shifted and changed, as the examination proceeds. No one can possibly foresee what the answers to a set of interrogatories are to be, and advantage cannot therefore be taken of the disclosures and suggestions which they contain for the purpose of developing further inquiries. In the third place, the interrogatories indicate, both by what they contain and by what they omit, the extent of the interrogator's knowledge, thereby aiding the deponent to conceal his case by enabling him to suppress all references to matters respecting which the examiner appears to be ignorant.

Many American states have imposed this limitation upon the method of discovery, and it has everywhere proved unsatisfactory for the reasons above suggested.

The new Illinois Civil Practice Act permits the use of either written interrogatories or an oral examination, and further provides that in case the deponent is hostile he may be examined as though under cross-examination. ${ }^{46}$ This enables the party seeking discovery to use whatever method seems best adapted to his purpose, and puts at his command the most effective device there is for bringing out the truth.

In regard, also, to the persons affected by it, the discovery offered by the new Tllinois Act goes much beyond the English rules. Only the parties to the action can be subjected to discovery examinations in England. ${ }^{47}$ Such a limitation undoubtedly reduces the effectiveness of the procedure as a general means for obtaining pre-trial information relative to the issues.

In Illinois, however, not only the parties but witnesses in general are to be subject to examination before trial. ${ }^{8}$ This makes it possible to call witnesses while their memories are fresh and before they have been privately interviewed or coached by counsel, and to put them on record regarding their observations and impressions. Such testimony is most likely to conform to the truth, and the depositions will make it difficult for witnesses to vary their stories after pressure has been brought to bear upon them by interested parties.

A considerable number of states have authorized this practice, making ordinary witnesses subject to discovery examinations, and in some of them the practice is quite commonly employed. ${ }^{49}$

$$
{ }^{46} \$ \text { ro5 (rule II) (x). } \quad 47 \text { Order } 3 \mathrm{I} \text {, rule I. } \quad 4^{8} \$ \text { IO5 (rule II) (I), (2). }
$$

49 See Ragland, Discovery before Trial, 50-53, showing that New Hampshire, Missouri, Ohio, Kentucky, Nebraska, Indiana and Texas authorize and use the practice of obtaining discovery from ordinary witnesses. 
Where a corporation is a party, and as such is to be subjected to a discovery examination, it is the rule in England that the particular officer or agent who shall be examined for that purpose is to be designated by order of the court..$^{50}$ In many of our states the statutes undertake to specify in detail the officers or other persons who may be so examined. Where there is a general right to examine ordinary witnesses, no specifications would be of any value, and in such states none is found.5r Tllinois expressly grants the unrestricted right to examine witnesses notwithstanding they are offcers, agents or employees of corporate parties to the action, by a provision that in such cases "the testimony of one or more of its officers, directors, managing agents, or employees, which is relevant, may be taken."s2

Finally, in regard to the scope of the subject matter open to discovery before trial, there has been in the past a great deal of reluctance to allow either party to prosecute inquiries into the facts of his opponent's case by means of discovery examinations. Under the old equity practice discovery was available for attack but not for defense. No party could be compelled to disclose his own evidence; he could only be forced to tell what he knew about the case of the party seeking the discovery..$^{53}$

This limitation, which largely destroys the usefulness of discovery as a means of preparation for trial, is still adhered to under the English rules, ${ }^{54}$ although both Ontario and Quebec have abandoned it. ${ }^{55}$ It is still adhered to in New York, ${ }^{56}$ Washington, ${ }^{57}$ New Jersey, ${ }^{58}$ Connecticut, ${ }^{59}$ and South Carolina. ${ }^{60}$

On the other hand, a number of states have abolished this restriction entirely, and permit discovery to be used freely to obtain information regarding either the case of the examiner or that of his adversary. Among these are Alabama, ${ }^{61}$ Indiana, ${ }^{62}$ Iowa,${ }^{63}$ Kentucky, ${ }^{64}$ Louisiana, ${ }^{65}$ Massa-

so Order 3r, rule 5 .

${ }^{5 \pi}$ Ragland, Discovery before Trial, 42.

54 Order 3I, rule I, note at 518 (Annual Practice, I933).

s5 Ontario Rules of Prac., rule 327; Quebec Code of Civ. Proc. Curran (r922), § 286.

${ }^{56}$ Civil Prac. Act, $\$ 288$; Oshinsky v. Gumberg, I76 N.Y.S. 406 (I9I9); Kimball v. Budd Co., 212 N.Y.S. 404 (I925). In Michigan, which took its discovery provisions from New York, the court has refused to follow the narrow construction given by the New York courts. Nestle v. Fleming, 262 Mich. 4I7, 247 N.W. 709 (I933); Vincent v. Van Blooys, 263 Mich. 3I2, 248 N.W. 633 (I933).

57 Wash. Rem. Comp. Stats. Ann. (r922), § I226; Hill v. Hill, I26 Wash. 560, 219 Pac. I8 (r933).

$5^{8}$ Wolters v. Trust Co., 65 N.J.L. I30, 46 Atl. 627 (1900).

s9 Pub. Acts of $x 93 x$, c. $252, \S 60$ ra.

60 People's Bank v. Helms, I40 S.C. ro7, $x_{3} 8$ S. E. 622 (x927).

6r Ala. Michie's Code (I928), $\$ 7764$. $\quad{ }^{6}$ Iowa Code (I931), $\$$ Irir85.

${ }^{62}$ Ind. Burn's Ann. Stats. (I926), $\$ \$ 564-5 . \quad{ }^{64} \mathrm{Ky}$. Carroll's Code (I927), $\$ 606$ (8).

${ }^{65}$ La. Dart's Ann. Prac. Code (1932), arts. 347-8. 
chusetts, ${ }^{66}$ Missouri, ${ }^{67}$ Nebraska, ${ }^{68}$ New Hampshire, ${ }^{69}$ Ohio, ${ }^{70}$ Texas, ${ }^{71}$ and Wisconsin..$^{72}$ This is the group in which Illinois has been placed by the new Civil Practice Act.

\section{THE USE OF JURIES}

Several important improvements have been made in connection with the use of juries.

In the first place, instead of making the jury the normal means of trial in an action at law, to be employed unless affirmatively waived, the situation has been reversed by the Civil Practice Act, and the case will proceed without a jury unless one of the parties affirmatively makes a demand for it. ${ }^{73}$ This, of course, fully protects the right of jury trial, but it will undoubtedly result in a gradual decline in the use of juries.

The jury is a very expensive luxury. The care with which it must be protected from facts supposed to mislead it, is the cause or the excuse for most of the subtleties of that extraordinary incubus upon the administration of justice, the modern law of evidence; the jury's ignorance of the law is the occasion for those elaborate technical instructions which judges give to juries and which constitute such prolific sources of error and reversal; and the jury's susceptibility to dramatic and emotional appeal is perhaps the chief stimulus to the unprofessional practices, in and out of the court room, which cause so much public criticism of the bar.

An additional inducement to waive the jury will be found in the abolition of the requirement that in non-jury law cases propositions of law should be submitted to the court and passed upon, as an indispensable basis for review, and that the court should, on the request of either party, make findings of fact which would have the force and effect of a jury's verdict. ${ }^{74}$ The new Act provides that such findings of law or fact shall not be necessary under any circumstances, either to support the judgment or as a basis for review. ${ }^{75}$ Their preparation always involved both difficulty and risk, for error might easily be introduced by the mere failure to adequately state, with technical accuracy, the principles of law which were actually employed or the facts which were actually proved. Under the new proce-

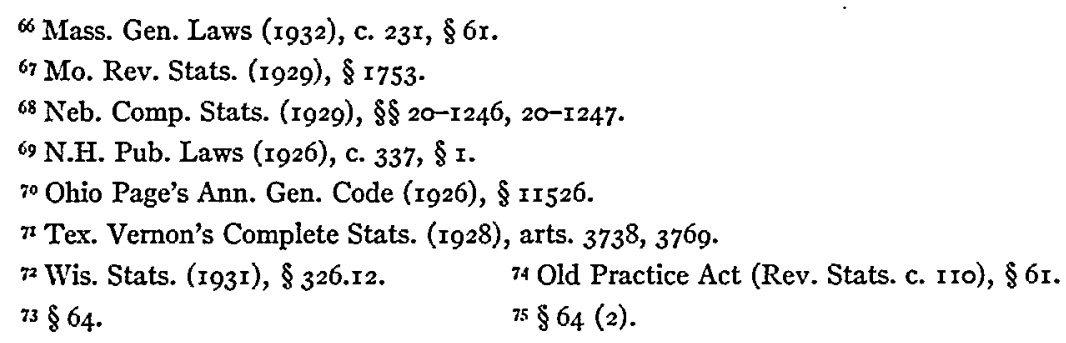


dure the parties will be entitled to whatever judgment can be shown to be proper as a matter of law on the basis of the facts actually established.

In the second place, the use of instructions has been made more effective and less hazardous, by requiring the judge to instruct the jury in writing in the form of a continuous and connected statement, and by giving the parties the right, out of the presence of the jury, to examine the instructions which the court proposes to give, and to make any objection or suggestion regarding them before the jury is charged. This will enable the court to remove errors in instructions before they reach the jury, instead of correcting them afterwards by destroying the verdict and ordering the case tried again. Furthermore, the Act declares that all errors in instructions not pointed out or preserved before the jury retires from the bar, will be deemed waived..$^{76}$

In the third place, the enormous economic waste involved in ordering a new trial as a remedy for error in the refusal of the court to direct a verdict, has been eliminated, by authorizing the entry of a judgment in such cases for the party who ought to have had a verdict directed in his favor. ${ }^{77}$

At common law the only cure for such an error was a new trial. Since a judgment could be entered only upon a verdict, it was impossible, after the verdict had been rendered for the wrong party, to enter a judgment for the right party. Although it was already established before one jury that a party was entitled as a matter of law to a judgment, it could not be given to him until he again established the same right before another jury, whereupon the second jury would be directed by the court to do what the first jury ought to have done. In such a case, both juries would be only judicial puppets, because there was no issue of fact for them to decide, but the law prohibited the court from acting in any way except through the formal agency of a jury.

Such a useless and expensive ritual, merely to preserve the appearance of regularity, is out of place in a modern judicial system, and a number of states have enacted statutes authorizing either the trial or the reviewing court, in case a motion for a directed verdict has been erroneously overruled, to enter a judgment for the party entitled to it without going through with the empty gesture of a new trial. Among these states are Massachusetts, ${ }^{78}$ Minnesota, ${ }^{79}$ Michigan, ${ }^{80}$ and Pennsylvania. ${ }^{81}$ Illinois has now joined this group. These statutes are constantly used, and enable

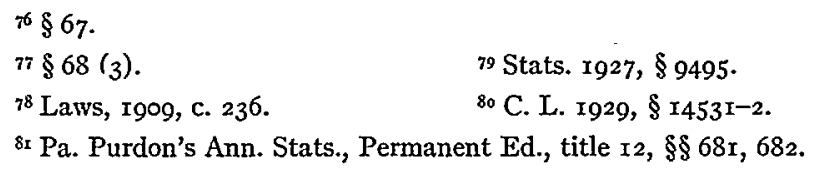


the court, in every case of doubt, by overruling the motion or by reserving its decision thereon (the latter being the method employed in the New Civil Practice Act), to get the benefit of the jury's verdict before discharging it, and then to give the question raised by the motion such careful consideration, with the aid of counsel, as the case demands. If, after such a study, the court is of opinion that the motion was or should be properly overruled, judgment will be entered on the verdict, while if satisfied that the motion was well founded, the court will enter a judgment contrary to the verdict. All the materials are present for finally disposing of the case either way, and no new trial will be necessary.

One of the amazing decisions of the United States Supreme Court was a decision in which, by a vote of five to four, the Pennsylvania statute authorizing this practice was held to contravene the Seventh Amendment to the United States Constitution preserving the right of trial by jury. This was the case of Slocum v. New York Life Ins. Co. ${ }^{82}$ in which a powerful and convincing dissenting opinion was written by Justice (now Chief Justice) Hughes, and concurred in by Justices Holmes, Lurton and Pitney. While this decision still precludes the use of the remedy in the federal courts, it has never been followed by any of the state courts, none of which have considered that it interfered with trial by jury in the slightest degree. ${ }^{{ }_{3}}$ In fact, as shown by Ezra $R$. Thayer, ${ }^{84}$ while it provides a more realistic procedure, it is in effect nothing but an adaptation of the wellrecognized common law practice of taking the verdict of the jury with leave reserved to enter a verdict for the other party if the court should be of opinion that he was entitled to it as a matter of law.

\section{REMEDIES OMITTED}

Two admirable remedies were proposed in the draft of the Act which was presented to the legislature, both of which were stricken out in the course of the debates.

One was an adaptation of the Wisconsin practice relative to special verdicts, following generally the English practice. Its purpose was to offer a substitute for the general verdict, which makes it necessary to give the jury general and often intricate instructions on the law, and which gives no specific indication as to how the jury decided particular questions of fact.

The other was a provision authorizing declaratory judgments. This has ${ }^{82} 228$ U.S. $3^{64}, 33$ Sup. Ct. 523 (1912).

${ }^{83}$ See Bothwell v. Boston Elevated Ry. Co., 215 Mass. 467 (r9r3); Stryker v. Montoursville Borough, 57 Pa. Sup. Ct. Ioo (rgr4); Kernan v. St. Paul City Ry. Co., 64 Minn. 312, 67 N.W. $7 \mathrm{r}(\mathrm{r} 896)$.

$8_{4} 6_{3}$ Univ. Pa. L. Rev. 585 (1914). 
become common practice in more than half the states and has proved to be an extremely useful and elastic remedy. Its rejection by the Illinois legislature is the more surprising because it followed closely upon the notable decision of the United States Supreme Court in Nashrille, Chattanooga and St. Louis Ry. v. Wallace, ${ }^{85}$ holding, after years of agitation both in and out of Congress, and after many adverse obiter dicta by the Supreme Court itself, that a case or controversy, within the meaning of the grant of judicial power by Article 3 of the United States Constitution, could be presented by a proceeding brought solely to obtain a declaration of rights.

${ }^{85} 288$ U.S. 249,53 Sup. Ct. 345 (1933). 